\title{
離島集落における空間構成上の特性と個と集団の「距離感覚」の関係性
}

\section{THE RELATIONSHIP BETWEEN THE CHARACTERISTIC OF SPATIAL COMPOSITION AND “THE DISTANCE SENSE" BETWEEN INDIVIDUALS AND GROUPS IN THE VILLAGES OF TOUSHI AND SUGA ISLANDS}

\author{
山本健 司*, 宮崎隆昌** \\ Kenji YAMAMOTO and Takamasa MIYAZAKI
}

\begin{abstract}
This study analyzes and evaluates "the distance sense" between individuals and groups in the villages of Toushi and Suga islands: Toushi, Wagu, Momotori, and Sugashima Villages. We have discovered that "the distance sense" of the individuals towards the groups is closely associated with these factors: the types and kinds of fishing industry, the evolving of the villages, and the various conditions of the neighboring environments. The closer to the rock and sand shore, the more activities are induced, hence, the rock and sand shore provides a multi-functional space for production, livelihood, and intermingling. As related to this, the closer to the rock and sand shore the house is, the more associated with outdoors the staying position of each family member is. Therefore, we suspect that the sensing system generated by "the distance sense" of the individuals in these villages, forms the environment of these villages, in which the residence, village, and environment unit with the rock and sand shore in their center, converge in a certain ranking order.
\end{abstract}

Keywords : Villages of remote islands, Dense population, Environment formation, Distance sense, Staying position 離島集落、高密集住、環境形成、距離感覚、常態位置

\section{1.はじめに}

\section{1 研究の背景と目的}

我が国では離島振興法指定の有人島は 260 存在する。そのうち、 漁業を生業とする世帯が多い集落では、離島という閉鎖系環境であ るために、磯・浜近傍の限られた領域内に自然環境と密接に関連し、 自然発生的に高密度な居住空間を形成してきた。漁港・漁協・店舗・ 住居が密集し、生産と生活が一体的に複合した高密集住空間での生 活は、自律した秩序を内包している。離島は飛地的立地であるため、 集落環境や漁場管理等は住民の自律的行動により行われる。さらに 漁業生産を通じた組合等の活動は、生産面のみならず様々な面で住 民同士の結びつきを担保し、慣習的に了解事項を成立させている。 その秩序とは、空間面では生活空間に融通性があること、生産面で は生産手段を共有することによる協㗢、生活面では相互扶助的共同 生活、集落環境の自主的管理等である。これらにより、高密度な居 住空間においても個々の生活者は集団との適正な「距離感覚」を有 しており、個我生活を確保し、かつ家族生活を維持しながら近隣社 会との共同的生活を持続することが可能となっていると考えられる。

多くの集落では、建築後数十年を経て老朽化した建物が多く存在 する。今後の集落環境は徐々に空間的・機能的に変化・対応が迫ら れると考えられる。集落環境を更新しつつも、生業（漁業生産）を 通じた地縁的コミュニティを持続するには、集落の空間構造と「個 人が持つ集団との距離感覚」（以下、「距離感覚」）の関係を明ら

かにし、集落環境の基盤形成を進める方途を検討する必要がある。 本研究は、住居単位・集住単位・環境単位の各次元で、個人とそ の家族および近隣の住民（以下、近所）との距離感覚が輻輳してい る集落として、三重県鳥羽市の 4 つの離島漁業集落を研究対象地と している。集落の空間構造・空間的特性および営む漁業形態の差異 等による「距離感覚」を分析・評価することを目的とする。

個人の生活が住居単位・集住単位・環境単位に輻輳する空間構造 において、物と物・物と人・人と人の関倸を明らかにすることによ り、漁業集落での高密集住を支える集住形式の仕組みを検討する。

\section{2 既往研究と本研究の関係}

漁業集落を対象とする主な既往研究 ${ }^{1) \sim 81}$ のうち、特に関連が梁い 研究として、宗・宮崎(1978a、1978b)は複合集落の形成過程を明確 にして生産・生活・交流にみられる重層性を明らかにしている ${ }^{12) 。 ~}$ 大内・宮崎ら(1986、1987)は漁協を中心にとらえた圈域をタイプ分 けし、遷移系列をもとに空間的遷移とその要因を明らかにしている ${ }^{3)+7}$ 。山本・宮崎（2003）は離島漁業集落を対象に隣家・近隣環境と の緩衝帯となる空間的装置・仕組みとして、作り付け収納が持つス ペーシング機能による集住形態を検証している ${ }^{5)}$ 。一方、都市部の 市街地を対象とし、関連がある研究として、仙田ら（1991、1992） は視覚的・心理的に落ち着く建築配置の指標として「建築の個体距 離」について研究している ${ }^{9110)}$ 。古賀・高橋(1997)は一人暮らしの高 齢者が住居内に形成する場について研究し、住まい方の特徽を明ら

* 日本大学大学院生産工学研究科博士後期課程 大学院生・工修

** 日本大学生産工学部建築工学科 教授·工博
Graduate Student, Graduate School of Industrial Technology, Nihon Univ., M. Eng. Prof., Dept. of Arch. College of Industrial Technology, Nihon Univ., Dr. Eng. 
かにしている ${ }^{11)}$ 。以上はいずれも居住環境や生活の質の向上におい て成果をあげて評価されている。しかし、離島漁業集落のように高 密度に居住空間が形成されている職住複合型環境において、個と集 団の結びつきを検討した研究は少ない。本研究は、有機的に形成さ れた自然発生的な環境依抛型の離島漁業集落を対象に、住居単位・ 環境単位の双方の視点から「距離感覚」を総体的に分析し、漁業集 落での高密集住を支える仕組みについて明らかにしようとしている。

\section{3 「距離感覚」の検眐方法}

本研究では、住居単位・環境単位の視点から、常態注 1)での「距 離感覚」を検証するため、住居内部空間において共有性が比較的高 い家族集合空間、家事・作業空間、住居内部空間に外部性が相互貫 入している近隣交流空間を取り上げる。そして、2つの概念を設定 し、以下の方法により研究を進める。

a)「常態位置」：住居内部空間での日常生活において、利用する頻 度が高く、使用・滞在時間が長い個人の特定の位置

b)「常態間距離」：常態位置同士の物理的空間距離

\section{(1)住居内部空間における個々の生活者の常態位直を把握}

住居内部空間において個々の生活者の常態位置を把握する (4.1)。 次に常態位置同士の位置関係（配列）を類型化し、常態位置の型と 住居の平面構成および周辺環境条件との関係を分析する (4.2)。

\section{(2)住居単位における「距離感覚」を検証}

様々な研究分野では、他者との関倸（心理的距離）は物理的空間 距離と密接に関係すると考えられている。そこで、常態間距離を算 出し（5.1）、潜在的に備わっている特性（スペーシング）を評価す ることで「距離感覚」を検証する（5.2）。さらに、常態間距離の長 さに応じて、常態位置同士を仕切る空間装置の存在形式を分析する ことで、「距離感覚」を支える空間的仕組みを検討する（5.3）。 (3)住居単位・集住単位・環境単位における「距離感覚」の輻䡮関俰

屋外空間での生産・生活・交流行為の実態を観察し、日常的な シキंウが「距離感覚」に与える影響を考察する（6.1）。さらに、 集落内での各住居の位置と常態間距離の関係を分析し、住居単位・ 集住単位・環境単位における「距離感覚」の輻輳関係を考察する (6.2)。

\section{2.研究対象集落の概要}

集落空間の構成・漁業形態の差異と「距離感覚」の関係を明らか にするため、類似した立地条件であり、採取したデータの比較が可 能であることを前提に、三重県鳥羽市の答志島（答志・和具・桃取） と菅島の 2 島 4 集落を研究対象地とした（Fig.1 - Tab.1）。各集落 ともに山・崖等の傾斜地を除いた非常に限られた平地に高密度な居 住空間が形成されている。各住居の空間的特性は生産作業空間が路 地空間に面することである。各住居には「外流し」（屋外の水洗い 場）があり、漁業に関する作業が行われる（Fig.2）。答志島の 3 集 落では、外流しと台所が上下水道・側溝等を共用するため台所は路 地空間に面し、住居内での家事・作業空間は屋外空間に近接してい る（Fig.3-1）。そのため、住居内部空間での生活の中心の場は路地 空間と近接・複合化し、個々の生活者は路地空間（外部）の状況を 視認しやすくなり、近所との物理的空間距離 - 心理的距離が輻輳し ている。しかし、菅島では外流しと台所は生活排水設備等を共用せ ずに台所は住居の最奥に位置することが多いため、答志島の 3 集落 とは違い、家事・作業空間は路地空間と近接していない（Fig.3-2）。

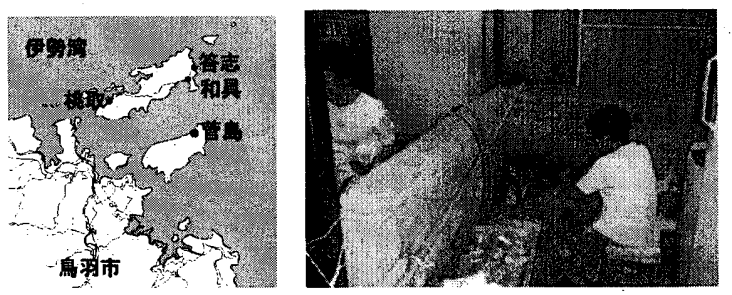

Fig.1 研究対象集落の位置 Fig.2 外流しでの生産作業（和具）

Tab.1 研究対象集落の概要

\begin{tabular}{|c|c|c|c|c|}
\hline & 答志 & 和具 & 桃取 & 管島 \\
\hline 裹落内の全世帯数 & 356世帯 & 153世帯 & 261世帯 & 215世帯 \\
\hline 調査世帯数 & $70 世 \frac{W}{巾}$ & 42世帯 & 51世帯 & 47世帯 \\
\hline 有効世带数 & 68世帯 & 41世帯 & 46世帯 & 39世帯 \\
\hline 全世带数に対する有効世带数の割合 & $19.1 \%$ & $26.8 \%$ & $17.6 \%$ & $18.1 \%$ \\
\hline 人口 & 1,471 人 & 542 人 & 968 人 & 828 人 \\
\hline 漁業形態 & 純漁村 & 主䚡従農村 & 半膿半漁村 & 純漁村 \\
\hline 属人水掦高(海面漁業) & $2,256 \mathrm{t}$ & $349 t$ & $384 t$ & $559 t$ \\
\hline 属人水揚高 (海面赛殖業) & $857 \mathrm{t}$ & $837 \mathrm{t}$ & $2,629 \mathrm{t}$ & $964 t$ \\
\hline
\end{tabular}

\section{3.铜查の概要}

現地調查は 2000 年 7 月から 2003 年 9 月にかけて 8 回実施した。 (1)建築物および屋外空間に関する実測調査では、調查員が集落内に ある全ての建築物および路地幅員を実測し、集落の詳細な平面図を 作成した。また、住居平面図をサンプル採取し、個々の生活者に「日 常生活および漁業者としての生活の実態」について詳細にインタビ ューした。(2)屋外空閒では行為観察調査を1日 3 回（7 時〜8 時、11 時〜 12 時、 17 時〜 18 時）実施した。そして、屋外空間での生産・ 生活・交流行為の実態を詳細に記述し、その状況を写真撮影した。

\section{4.住居内部空間における個々の生活者の「常態位置」 4.1「常態位置」の設定および特定方法}

漁業集落での個人の生活は、漁業者としての生活と家族構成員と しての生活がある。それらの生活時間帯がずれる場合は、前者に後 者を合わせる形態をとる。個人の住居内生活は時期や漁業形態によ り多少の相違があるが、各集落とも一般的に次のとおりである。

世帯主は、午前 3 時頃に出漁して午前 7 時頃に漁協で漁獲物を選 別・出荷する。昼頃に食事のために帰宅し、午後は休款または漁網・ 漁具の手入れ等を行う。仕事後は磯・浜へ出て近所と翌日の出漁に 関する打ち合わせ等準備の為に過ごす事が多い。その後は家族と団 樂・食事等の家族生活を営み、午後 8 時頃に就寝する世帯が多い。 基本的に起床・就寝時刻が早く、住居内には限られた時間帯しか滞 留しないため、世帯主の住居内生活は主に団綝・食事等に象徵され る。一方、主婦は基本的には世帯主の漁業生産に対応した生活を営 み、家事の他に漁網の修理・水揚げ作業など操業前後において協働 する。ある特定の解禁日には海女漁業を行うことや自家用程度に農 作業を行うことがあるため、主婦の主な住居内生活は家事・作業行 為に象徵される。各集落とも地縁的・血縁的なつながりをもとに近 所と親密に付き合っているため、近所が物品等を持って訪問するこ とや出入り口に腰掛けて会話や情報交換等を行っている。

本研究では、上述の住居内生活を特に象徴する場として、家族集 合空間 (常学注2) )での団絸・食事等を行う世帯主の常態位置を「D」 (Docking position)、家事・作業空間 (カ⿱亠亠䒑十) での家事や漁具の手 入れ等の生産作業を行う主婦の常態位置を「H」(Housekeeping

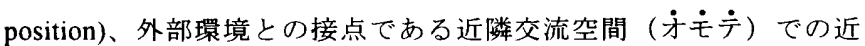
所の常態位置を「N」(Neighborhood position)とする (Fig.3-1〜Fig.3-5)。 
調查員はサンプル採取した住居平面図をCAD で整理した後に、改 めて各住居を訪問した。常態位置を特定するにあたり、調査員は「世 帯主には団樂・食事等を行う位置、主婦には家事や漁具の手入れ等 の生産作業を行う位置、また両者には近所が訪問した際に交流を行 う位置」についてそれぞれ指示・説明を受け、案内された位置を持 参した図面に記入することで把握し、各居住者に再度確認を受けた。

\section{2「常態位置」と住居の平面構成 - 周辺環境条件の関係}

常態位置を規定する要因を把握するため、住居の表層性・奥性と の関係を分析する。住居内部空間と外部環境との接点であるす் （「N」）から住居内部をみた場合の常態位置（「D」「H」）の位 置関係を、常態位置の配列に応じて以下の型に分類する（Fig.4）注 ${ }^{3)}$ 。室の構成や常態位置同士の結びつきを考慮して、A〜C type では、

「D」「H」「N」のうち2 者のみが間口方向上に並ぶ型として、A type は「N」「H」が間口方向上に位置する型（Fig.3-1）、B type は「D」 $\lceil\mathrm{H}\rfloor$ が間口方向上に位置する型（Fig.3-2）、C type は「N」「D」 が間口方向上に位置する型（Fig.3-3）とする。D type は「D」「H」 「N」が互いに独立性が高く、間口方向上に並ばない型（Fig.3-4）、 E type は「D」「H」「N」3 者が間口方向または奥行き方向、斜方 向に一直線上に位置する型 (Fig.3-5) とする。

常態位置の型別の占有率を Fig.5 に示す。A type は答志が $73.5 \%$ と 最も多く、次いで和具が $53.6 \%$ 、桃取が $38.2 \%$ 、菅島が $5.1 \%$ あ゙あ た。逆に、B type は菅島が $61.6 \%$ と最も多く、桃取が $28.2 \%$ 、和具 が 19.5\%、答志が 10.2\%であった。A type では「H」は住居の方主 側に位置して路地空間に面することが多く、「D」は「H」と近接す
るとともに外部の状況を容易に視認できる場所に位㯰することが多 い。B type では「H」は住居のウう（方う）側に位置することが多 い。「D」からは外部の状況を視認することはできないが、「H」と 近接して一体的な関倸を持つことが多い。

集落ごとに少数な常態位置の型の周辺環境条件をまとめる。

A type では、菅島は該当数が少なく、明確な傾向はみられない。 B type では、答志・和具は路地に 2 方向接する住居に多く、「H」

「N」は間口方向上に並ばずに互いに表・裏の路地に面する。C type では、各集落ともオ主側に前庭や植栽を配置する余白空間を持つ など、敷地条件に余裕がみられる。前庭に面した室を居間として利 用することで、出入りロ・居間・前庭が一体的な関係を持ち、「D」 $\lceil\mathrm{N} 」$ が間口方向上に並ぶ。他に「N」を基点に「D」「H」が $\mathrm{L}$ 字 状に路地空間に面する事例もある。D type では、答志・和具は敷地 が狭溢で 2 室しかない狭小住居に多く、「D」「H」「N」が独立し て位置することで互いの距離を保っている。桃取では傾斜地に位置 することが多い。E type では、各集落とも短冊状の宅地割に多い。

集落が自然発生的に形成される過程で、各住居の出入り口・台所・ 外流し・開口部・作り付け収納等の位置は、住居の並び方・路地と の関係（接道面数・長さ等）・近隣住居との近接性・生活排水設備 等に規定されてきた。「H」は家事・作業行為に必要な水迴りがあ る空間またはその近辺、「N」は出入り口付近として、住居平面の 影響がみられる。常態位置の型は答志・和具では A type、桃取では A・B type、菅島ではB type を主としつつ、各住居の敷地形状や周 辺環境の条件に合わせてその他の型へと派生していると考えられる。

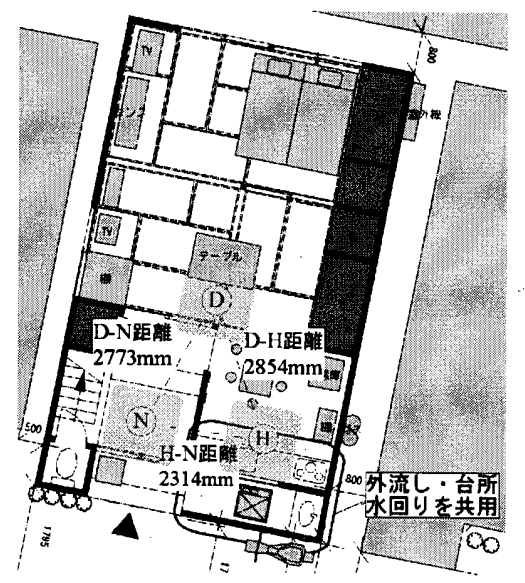

Fig.3-1 答志 SN62 : A type

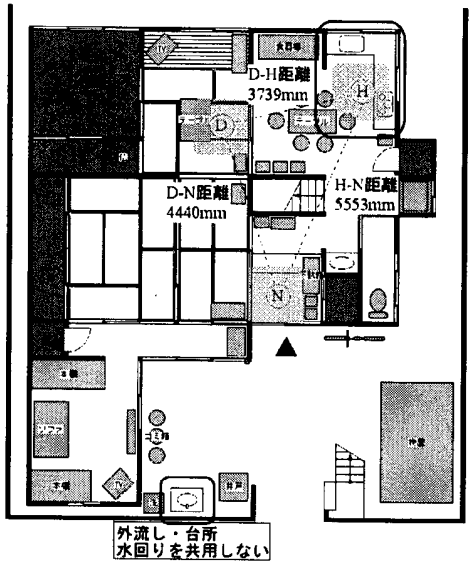

Fig.3-2 菅島 SN29：B type

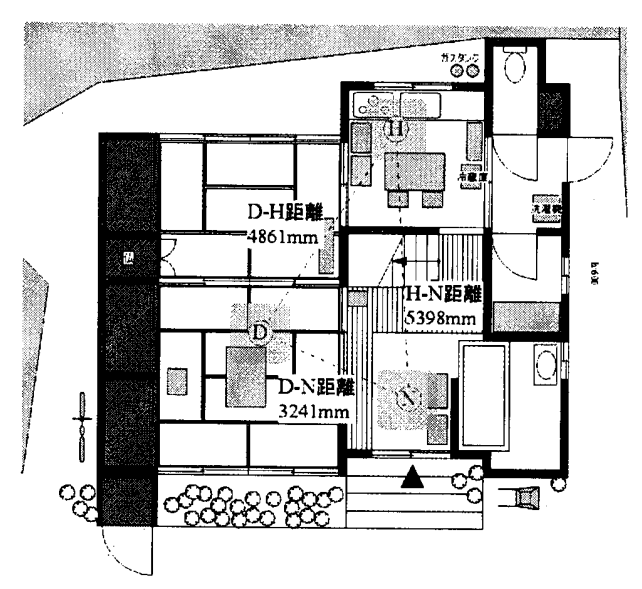

Fig.3-3 桃取 SN34 : C type

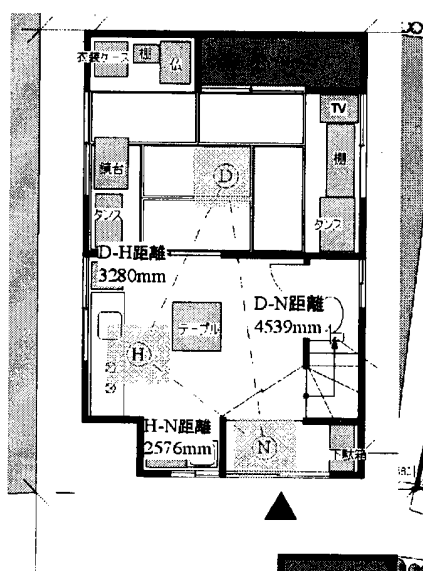

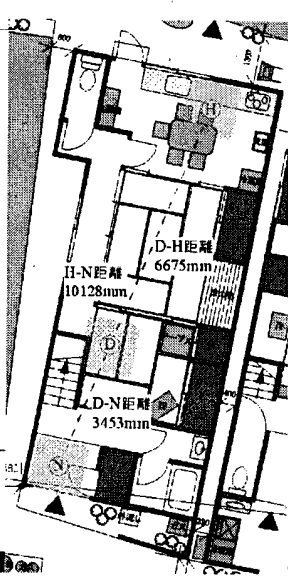

Fig.3-4 和具 SN32 : D type Fig.3-5 答志 SN39 : E type

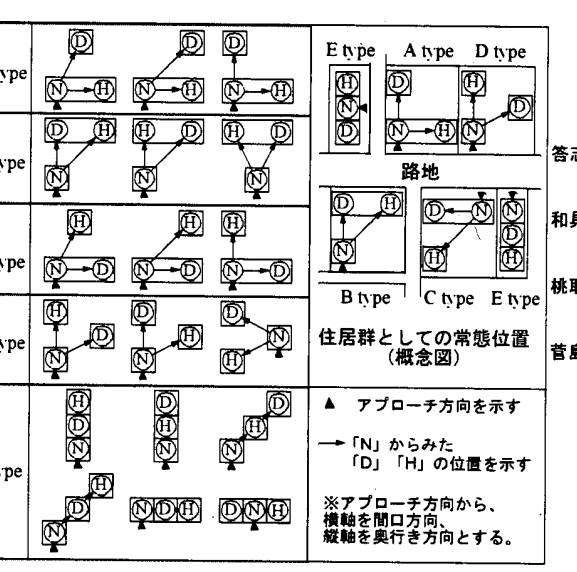

Fig.4 常態位置の型

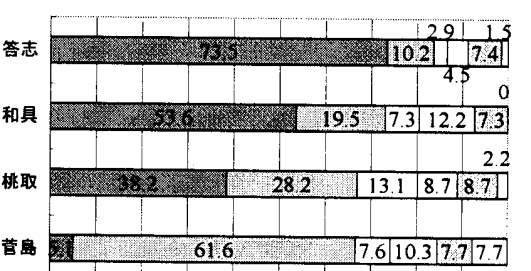

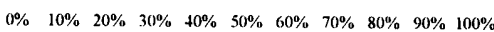
G A type $\square$ B type $\square$ C type $\square$ D type $\square E$ type Dother

Fig. 5 常態位置の型別の占有率 


\section{5. 個々の生活者が持つ集団との「距離感覚」}

常態位置が間仕切り等の空間装置を挟んで位置する状況では、両 者の汁注认が遮断・伝達する事で「距離感覚」を保つと考えられる。

「距離感覚」を検証する第 1 段階として常態間距離を直線距離とし て算出し、集落別にどのような差異があるかを把握する（5.1）。第 2 段階ではエドワード・ホールが提唱する「Proxemics」という概念 を用いて常態間距離に潜在する特性を評価する。離島漁業集落のよ うな高密集住空間ではどのような「距離感覚」を保っているのかを 総体的に検証する (5.2)。第 3 段階では常態位直の型別に、常態間 距離の長さに応じて両者の間にどのような空間装置が存在するかを 分析することで「距離感覚」を支える空間的仕組みを検討する (5.3)。

\section{1 常態間距離」の算出}

常態間距離はCAD を用いて常態位置同士の直線距離を計測 する。多くの住居は和室を中心に構成され、回遊性・融通性が 高い。状況ごとに動線を任意に選択できる経路距離に比べて、 直線距離は単一で固定的な安定した指標となる。また、常態位 置同士を結ぶ直線とそれに交差する空間装置の関係により「距 離感覚」を成立させるのに必要な空間装置の形式が明確になる と考えられる。両者の間に存在する空間装置の影響は（5.3） で検討する事とし、ここではそれらの有無に関わらず、直線距 離を計測する。「D」に世帯主・「N」に近所が居る状況の常態 間距離を D-N 距離、「H」に主婦・「N」に近所が居る状況の常 態間距離を H-N 距離、「D」に世帯主・「H」に主婦が居る状況 の常態間距離を D-H 距離とする（Fig.3-1〜 Fig.3-5）。世帯主と 近所の関係は D-N 距離、主婦と近所の関係は H-N 距離、世帯 主と主婦の関係は D-H 距離に潜在する特性として評価する (Tab.2)。Fig.3-1 では、D-N 距離 : 2,773mm、H-N 距離 : $2,314 \mathrm{~mm}$ 、 D-H 距離 : $2,854 \mathrm{~mm}$ となる。Fig.6 に集落別の常態間距離の平 均值を示す。常態間距離は答志では家族同士より近所との方が 短い (D-N 距離 $<\mathrm{H}-\mathrm{N}$ 距離 $<\mathrm{D}-\mathrm{H}$ 距離)。和具では家族同士の 方が近所よりも短い（D-H 距離 $<\mathrm{D}-\mathrm{N}$ 距離 $<\mathrm{H}-\mathrm{N}$ 距離）。桃取 では家族同士と近所はほぼ同じ距離を保っている(D-N 距離う $\mathrm{H}-\mathrm{N}$ 距離 家族同士の方が近所より短い ( D-H 距離 $<\mathrm{D}-\mathrm{N}$ 距離 $<\mathrm{H}-\mathrm{N}$ 距離)。 これらと (4.2) の結果より、常態間距離は A type が多い集落 では家族同士よりも近所との方が短く、B type が多い集落では 家族同士の方が近所よりも短いといえよう。答志島・菅島での

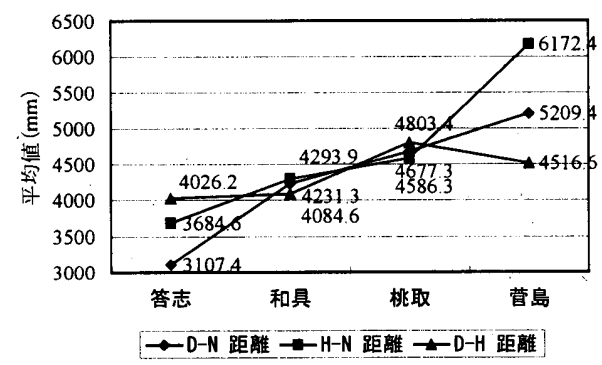

Fig.6 常態間距離の平均值

Tab.2 常態位置と常態間距離

\begin{tabular}{|c|c|c|}
\hline 常態位 & 置(Staying position) & 常態間距離と個体間の関係性 \\
\hline 世帯主 & Docking position & D-N距離 : 世带主と近所の関係を示す物理的空間距離 \\
\hline 主婂 & Housek & H-N距離 : 主始 \\
\hline & & D-H距離: 世帯 \\
\hline
\end{tabular}

常態間距離は、次のような集落の背景との関連も考察できる。

(1)住居が位置する周辺環境条件の差異として、地割りや敷地の狭 小性・排水路や道路の取り付け等がある。答志では出入り口側以外 の 3 面を住居で囲まれることが多く、外流しは出入り口側に位置す る。外流しと台所が水迴りを共用するため、台所も出入り口に隣接 する。生活の中心である「D」「H」は路地空間と近接するため、個々 の生活者と近所との常態間距離（D-N 距離・H-N 距離）が短いと考 えられる。和具・桃取は住居の並びが様々であるために 2,3 面に路 地が接する住居も多い。必ずしも外流し・台所等の家事・作業空間 は出入り口側に位置せず、常態間距離は答志に比べて長い。菅島は 答志と同様に外流しは出入り口側に位置するが、台所は住居内最奥 に位置し、家事・作業空間と出入り口付近の近隣交流空間は分離す ることが多い。家事・作業空間だけでなく家族集合空間も奥側に位 置し、D-N 距離・H-N 距離は長く、D-H 距離は短いと考えられる。

(2)営む漁業形態の差異として、答志は純漁村であるために世帯主 は漁船漁業、主婦は海女漁業を行い、両者共に常に近所や仕事仲間 との連携が必要である。逆に、和具では世帯主は漁船漁業を行うが、 主婦は答志に比べて海女漁業に従事する割合が少なく、農業を営む ことが多い主漁従農村であり、比較的世帯の独立性が高い。桃取は 半農半漁村であるために、さらにその傾向が顕著である。菅島は純 漁村であるが、海面漁業における属人水揚げ高が答志に比べて非常 に低い（Tab.1）。答志（純漁村）では和具（主漁従農村）・桃取（半 農半漁村）に比べて生業を通じた地域共同体意識が「距離感覚」と して表れ、常態間距離が短いと考察できる。しかし、純漁村でも漁 業生産高が低い菅島では、比較的世帯の独立性が高くなり、家族同 士の方が近所よりも結びつきが強く、D-H 距離が短いと考えられる。

(3)集落行事（慣習）や漁場管理の方法によるものとして、答志・ 和具では無形文化財に指定されている寝屋子制度等があるため、生 活扶助機能・共同作業が助長され、成人後も親密な人間関係を保っ ている。それを下敷きにして、生産組合の形成単位や技術伝承・情 報交換が円滑に行われている。許可漁船漁業は漁船単位で生産活動 を行うため、船主・船頭・船子等の協働的結合を軸に共同体を形成 している。桃取では、地先漁業の区画漁業権を行使する養殖漁業が 主であり、私企業的な家族経営の生産活動が優先している。苩島は 専有漁業権による磯根漁業であり、採取（潜水漁）が海女集団・夫 婦単位で行われているために、婦人の漁業就労を前提としている。

(4)集落の形成プロセスの相違として、答志は背後地に山・崖等の 傾斜地があり、居住空間は背後地に広がる余地を持たず、居住空間 は背後地から海側にかけて埋め立てを繰り返しながら徐々に形成さ れた。一方、和具は背後地に畑地があり、居住空間は畑地にスプロ 一ルして海側から背後地にかけて形成された。桃取・菅島での居住 空間は海側から背後地の山・崖等の傾斜地にかけてスプロールする とともに、背後地から海側にかけて埋め立てを繰り返してきた。

Fig.6・Tab.1 より答志島・萛島での常態間距離は、漁業生産の占 める割合が高い集落ほど家族同士より近所との方が短く、その割合 が低い集落ほど家族同士の方が近所より短い傾向がみられた（住居 内部空間での「D」「H」は漁業生産の占める割合が高い集落ほど屋 外空間に近接している）。これは限られた地域での結果であり、集 落の様々な側面での背景との関連が考察できるため、漁業集落一般 論と寸るには異なる背景を持つ他の集落との比較検討が必要である。 


\section{2 「常態間距離」の評価}

エドワード・ホール(1966)は「Proxemics」という概念を提唱し、 動物にみられるスペーシング機能と同様に人間にもその機能がみら れるとしている ${ }^{12)}$ 。様々な場面で個人が他者と接するときに使用 する距離は 4 種類あり、それぞれの距離に近接相と遠方相が存在す ることを見出した。4 種類の距離とは密接距離 $(0-45 \mathrm{~cm})$ ・個体距離 $(45 \mathrm{~cm}-1.2 \mathrm{~m}) \cdot$ 社会距離 $(1.2-3.6 \mathrm{~m}) \cdot$ 公衆距離 $(3.6 \mathrm{~m}$ 以上)であり、各々 に潜在する特性が異なるとしている。また、自己を中心にある範囲 内は泡（風船）の様な空間で曲まれ、他者との距離を保つ事を示唆 している。ホールの距離概念をふまえた既往研究として、仙田ら （1991、1992）は視覚的・心理的に落ち着く建築配置として建築相 互間にも個体距離が存在すると結論付けている ${ }^{99}$ 。そして居住環境 の評価の視点には、隣戸の音・視線・に方い・通風・日照等の環境 条件を評価する指標が不足していると述べている ${ }^{10)}$ 。仙田らは屋外 空間の視点から建築の個体距離を検討しているのに対し、本研究は 住居内部空間の視点から距離感覚を検討していると位置付けられる。

住居内部空間での日常生活では、個人と他者が間仕切り等の空間 装置を挟んで位置する状況が想定できる。互いに視線が遮断されて いても物音など五感を通じて、両者のけほいが伝達・遮断する事で 互いの存在を意識し、心理的・物理的空間距離を保つと考えられる。 本研究での「距離感覚」は、「視覚を中心としてに求けや物音等を 総合したけはにによって、個体間に保たれる心理的・物理的空間距 離」と捉える事が重要であり、ホールの距離概念との前提が同様で あるために常態間距離に潜在する特性は「Proxemics」の概念により 評価する。Fig.7 にホールが提唱する 4 種類の距離別に住居の占有率 を示す。答志では D-N 距離・H-N 距離は社会距離・遠方相 $(2.1-3.6 \mathrm{~m}) 、$ D-H 距離は公衆距離・近接相 (3.6-7.5m) が最も多い。他の 3 集落 では各常態間距離とも公衆距離・近接相 (3.6-7.5m) が最も多い。 一般的に、社会距離・遠方相，(2.1-3.6m）はドアが開いていれば隣 室から他者の話し声を聞き取れると同時に、他者を気にせずに自分 の行動に集中できるといわれている注”。個々の生活者と近所との常 態間距離（D-N 距離・H-N 距離）がこの間隔を保つことは、住居内 に居ても訪問者に対して適切に忘対することや外部の情報を容易に 視認でき、近所との交流を誘発・制御するのに適切な距離と考えら れる。公衆距離・近接相 (3.6-7.5m) は個人的関倸が成立しにくく なる距離であり、互いに独立した行為を行うことができる。高密集 住空間ゆえに各住居の建築面積が非常に狭小である事を考慮すると、 奥側を常態位置として常態間距離を長くし、奥性を高めることが家 族生活を確保するための心理的影響と考えられる。しかし各常態間 位置は非常に短く（Fig.6）、答志では D-N 距離・H-N 距離が社会距

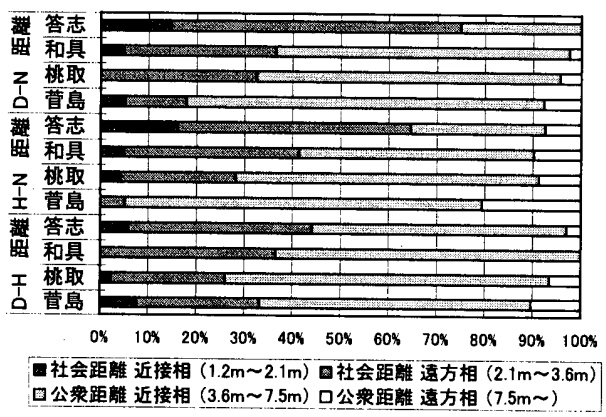

Fig.7 エドワード・ホールが提唱する 4 つの距離別の占有率 離・近接相（1.2-2.1m）である住居が 15\%前後も存在する（Fig.7）。 $「 \mathrm{H} 」$ は水迴り空間またはその近辺、「N」は出入り口付近としてあ る程度定型化される。「D」は物理的・空間的に規定されず任意で ある。「D」は、表層としての路地・土間・タタキを介して、家族 や近隣集団との相互扶助的共同生活を維持・調整し、相補し合う意 識や漁業生産が共同作業である社会構造の影響も考察できよう。

\section{3 住居単位における「距離感覚」を支える空間装置の存在形式}

常態位置同士を仕切る空間装置の存在形式を「なし、引き違い建 具、壁、引き違い建具と壁、ドア、2 種類以上の装置（「引き違い 建具と壁」以外の組み合わせ）、その他（いずれにも該当しないも の）」に分類し、ホールが提唱する距離ごとに該当住居数を集計す る。Fig.3-1 (A type) は各常態間距離とも社会距離・遠方相 (2.1-3.6m) に該当し、「D」「N」を仕切る空間装置は「引き違い建具」、「H」 「N」は「壁」、「D」「H」は「なし」として集計する。

\section{a)「D」と「N」の「距離感覚」を支える空間装置}

Fig.8-1より、A type は「D」「N」を仕切る空間装置が「なし」、 存在する場合は「引き違い建具」が最も多い。D-N. 距離が $2.1 \mathrm{~m}$ 以 上になると「2 種類以上の装置」が増加する。B type はホールの分 類するどの距離にも「引き違い建具」が存在し、D-N 距離が $2.1 \mathrm{~m}$ 以上になると「引き違い建具と壁」「2 種類以上の装置」が増加す る。C type は D-N 距離が $3.6 \mathrm{~m}$ 程度までは「壁」が多く、 $2.1 \mathrm{~m}$ 以上 から「引き違い建具」がみられた。D・E type では「その他（階段 や作り付け収納）」が存在する事例がある。A・B type では D-N 距 離が短いと空間装置が存在しない割合も高く、長くなると可動式か ら固定式になるが、C type では固定式から可動式となる傾向がある。

\section{b）「H」と「N」の「距離感賞」を支える空間装置}

Fig.8-2 より、A type は「その他」を除くと、H-N 距離に関わらず 「壁」が最も多く、次いで「引き違い建具と壁」が多い。B type は H-N 距離が短い場合は「壁」、長くなるに従い「その他（階段）」 が多くなる。C type は「引き違い建具」「壁」を基本とする。D type は H-N 距離が短いほど「引き違い建具」が多く、3.6m 以上から「引 き違い建具と壁」「壁」というように可動式から固定式となる傾向 がある。E type は H-N 距離が長くなるに従い空間装置の数が増加す る。A・B type は H-N 距離に関わらず固定式装置が多いが、D type は H-N 距離が長くなるに従い、可動式から固定式となる傾向がある。 c）「D」と「H」の「距離感覚」を支える空間装置

Fig.8-3 より、A・B type は D-H 距離が短いと「D」「H」を仕切る 空間装置が「なし」の割合が高く、存在する場合は「引き違い建具」 が多い。D-H 距離が $3.6 \mathrm{~m}$ 以上になると「引き違い建具と壁」「2 種 類以上の装置」が多くなる。C type は D-H 距離が長い事例では「そ の他（階段・収納）」がある。D type は「引き違い建具」が多く、 $3.6 \mathrm{~m}$ 以上では「引き違い建具と壁」「壁」もある。E type は D-H 距 離が短いと「なし」、存在する場合は「引き違い建具」が多い。

a)〜c)より常態位置の型・常態間距離・常態位置を仕切る空間装 置には相互補完関係があると考えられる。常態位置の基本型である A・B type では、常態位置同士を仕切る空間装置は「引き違い建具」 を主とする。D-N 距離・D-H 距離が短くなると空間装置が存在しな い事や可動式装置が多いのに対し、H-N 距離が短いほど固定式装置 が多い。個々の生活者はこれらの空間装置を日常的・非日常的に適 宜使い分け、近所との交流を容易に誘発・制御しているといえよう。 
6.住居単位・集住単位・環境単位における「距離感覚」の輻䡣関係 6.1 日常生活での行為からみる「距離感賞」

屋外空間で行為観察調查を実施し、生産・生活・交流の実態を把 握する。離島漁業集落での磯・浜は生産・生活・交流の場として大 きな役割を果たす。(1)漁業生産作業の場(2)水産物の荷別きの場（搬 出入・市場）(3)漁業協同組合の場(4)島内外を結ぶ海上交通の拠点(5) 漁業に関する準備・打ち合わせ等を通じたコミュニティの場(6)漁船 を倸留する場等である。そこで、磯・浜に面する地区を A 地区（2 方向に磯・浜がある場合は漁協と反対側を $\mathrm{A}^{\prime}$ 地区）、店舗等がある 市街地区を B 地区、背後に山・崖等の傾斜地がある最奥地区を C 地 区とする（Fig.9-1～Fig.9-4）。金・高橋（1995）は、都市部の密集 市街地を対象に行為観察調查を行っている ${ }^{13)}$ 。J.ゲールの屋外空間 での活動の分類を参考に、人々の行動を「社会行動・任意行動・必 要行動」に分類し、社会行動が多いほど屋外空間は活発であるとし ている。漁業集落の屋外空間では、都市部の屋外空間でみられる行 為の他に、外流しでの生産行為、漁業に関する打ち合わせ、操業前 後の準備・後始末、漁網の修理等の行為がみられる。そこで、前出 の文献を参考に屋外空閒での行為を Tab. 3 のように分類する。集落 ごとに各地区の面積に相違があるため、各地区で観察した行為を $50 \mathrm{~m} \times 50 \mathrm{~m}$ 内の行為数と行為内容の割合として算出した（Fig.10-1〜 Fig.10-4)。答志・和具・桃取では B 地区で最も行為数が多い。A 地区・A'地区では B 地区に次いで行為数が多く、社会行為は最も多 く観察できた。菅島では A 地区で行為数と社会行為が最も多く観察 できた。一方、各集落とも C 地区は最も行為数が少ない。離島は飛 地的立地であるため、海岸線は海（外）と島（内）を仕切る境界線 的役割を果たし、地井論文 ${ }^{6) 7}$ てよる限界環境として立地している。 海岸線から背後地（内）にかけて連続する磯・浜（A 地区）は、漁 業者が波風等の天候状態や海（外）の様子を日々確認するのみなら ず、夕涼みや散歩・近所との立ち話等の交流の場として機能する (Fig.11・Fig.12-1)。いわば、庭を持たない狭小な住居内生活を補 完する三ウとして機能する。漁港は島（内）と海（外）の接点であ るデイウグチとして機能する。B 地区では、近所が物品等を持って 訪問し、出入り口に腰掛けて会話する様子、外流しでの生産作業中 に歩行中の近所と会話をする様子（Fig.2）、屋外にいる近所が開口 部を通じて住居内の生活者に話しかける様子等が数多く観察できた。 また、屋外空間には井戸・洗い場が数多く存在する。現在では水汲 み場として利用されていないが、慣習的に近所との共同の場として

機能し、集住単位の結びつきを維持している (Fig.12-2)。以上(1)磯・ 浜に近いほど屋外空間では多くの行為が発生し、特に社会行為が最 も多く、生産・生活・交流の中心として機能している(2)住居の「内 と外において住民同士のシキううが連続的であることがいえよう。

\section{2 集落内における各住居の位置と「距離感覚」の関係}

離島漁業集落での磯・浜は非常に大きな役割を担い、活発に機能 している。本項では環境単位の視点として、磯・浜のなかでも特に 中核的な場である漁協を基点とした各住居の位置と常態間距離の関 係を分析することで、「距離感覚」の輻輳関係を考察する。まず、 漁協を基点に各住居までの距離（漁協の中心点と各住居の中心点を 直線で結ぶ最短距離）を算出する。次に、漁協を $0 \mathrm{~m}$ 地点として $30 \mathrm{~m}$ 毎の同心円を想定し（Fig.9-1～Fig.9-4）、漁協から各住居までの距 離が同じ同心円に含まれる住居において、各常態間距離の平均值を 求める（Fig.13-1～Fig.13-4）。但し、磯・浜（漁協）近傍で漁業生 産に関する施設や公共施設・店舗等が集中し、住居が存在しない区 域は除外する（答志・和具 : 0-30m 区域、挑取・菅島 : 0-60m 区域）。

Tab. 3 行為分類

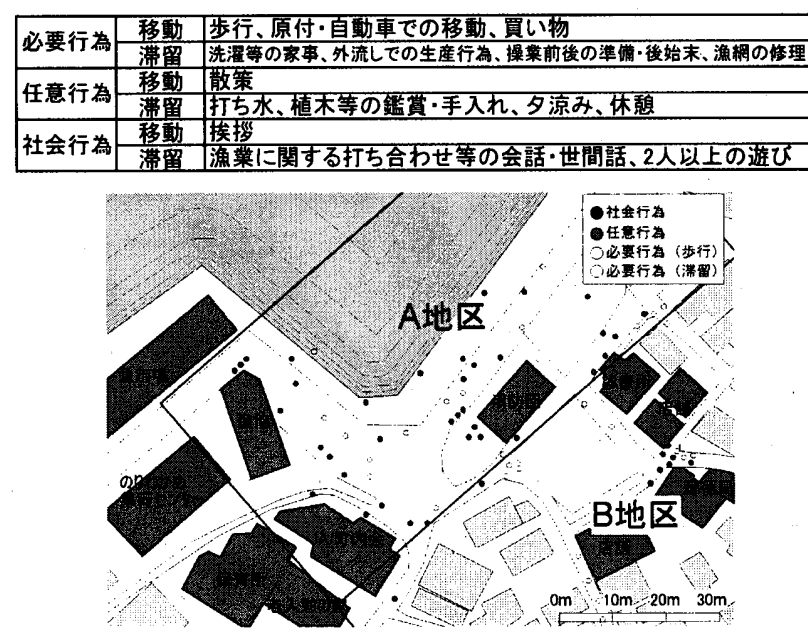

Fig.11 行為観察調查（菅島 A 地区 : 2003.9.7. 17 時〜18 時)
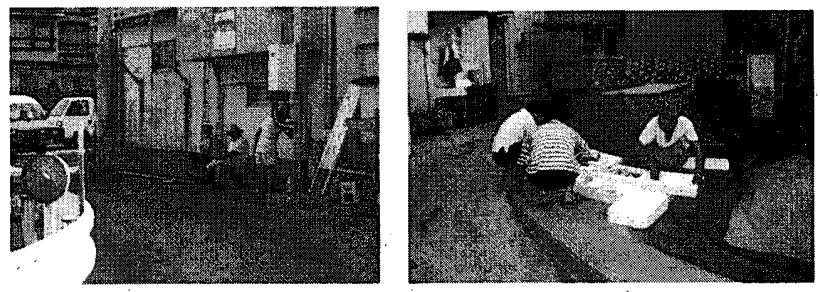

Fig.12-1 磯・浜での会話 ${ }_{60}$ (菅島) Fig.12-2 井戸での協働（和具）

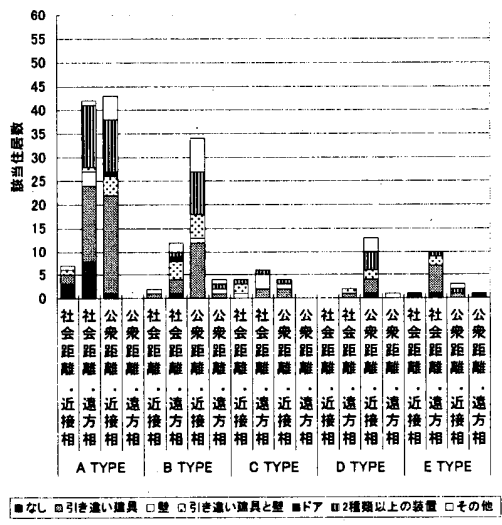

Fig.8-1「D」「N」を仕切る空間装置

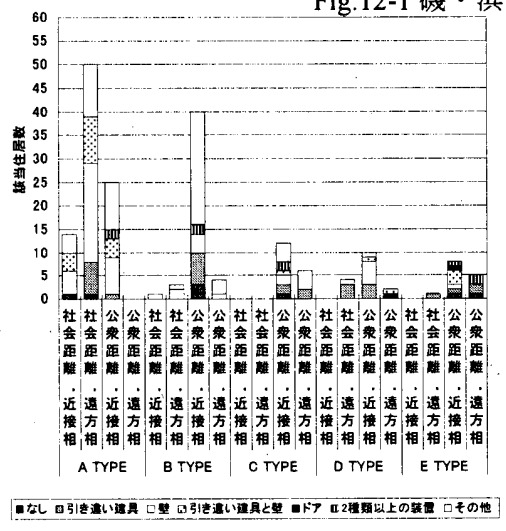

Fig.8-2「H」「N」を仕切る空間装置

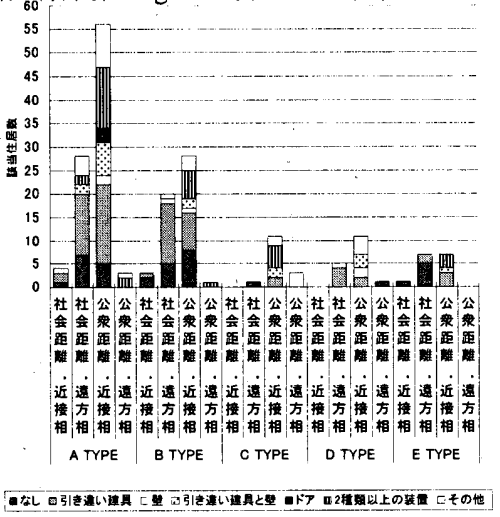

Fig.8-3「D」「H」を仕切る空間装置 
答志では磯・浜 (漁協) 近傍の住居ほど各常態間距離は短く、遠く に位置する住居ほど各常態間距離は長い（Fig.13-1）。つまり、磯・ 浜 (漁協)に近い住居ほど、住居内部空間での常態位置「D」「H」 が屋外空間に近接していることを表している。これは、前項で観察 した屋外空間での行為とも関連する。磯・浜に近いほど屋外空間で は漁業生産を通じた近所との共同作業が活発に行われる事や生活の 相互扶助機能がみられる事により、磯・浜（漁協）近傍の生活者は、 住居内での生活の中心の場を屋外空間に近接させている。住居内の 生活者と屋外空間の近所を仕切る空間装置が引き違い建具である事
が多いため、両者の物理的空間距離が短くても容易に交流を誘発・ 制御できる。このような仕組みにより、磯・浜（漁協）近傍に住ま う生活者は個我生活を確保し、かつ家族生活を維持しつつも、共同 的生活を持続している。和具は答志と違い、(120-150m)地点で常態 間距離が大幅に短くなる (Fig.13-2)。和具は東西を2つの磯・浜に 挟まれるためと考えられる。つまり、(120-150m)地点では東側の磯・ 浜の影響で、漁業生産に関する作業が多く行われることに関連して 常態間距離が短くなっている。桃取では $(210-240 \mathrm{~m})$ 地点が変曲点と なり、常態間距離は短くなる傾向がある（Fig.13-3）。桃取も和具と

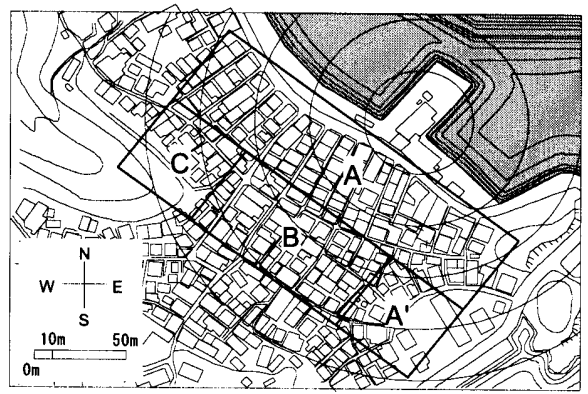

Fig.9-1 集落地図（答志）

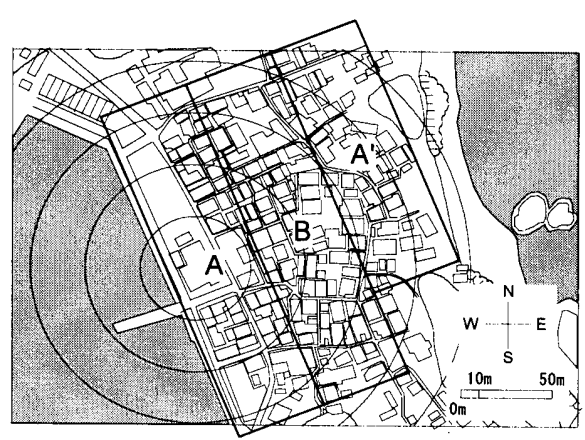

Fig.9-2 集落地図（和具）

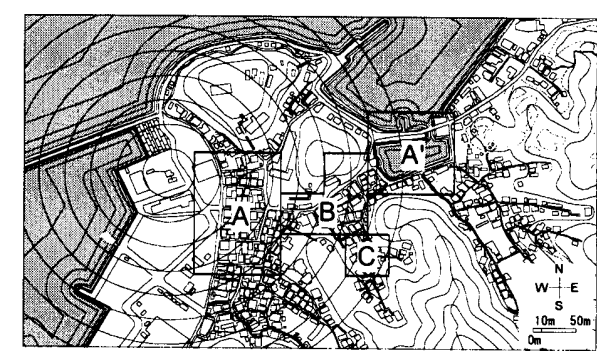

Fig.9-3 集落地図（桃取）

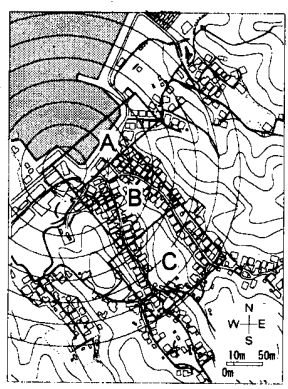

Fig.9-4 集落地図（菅島）

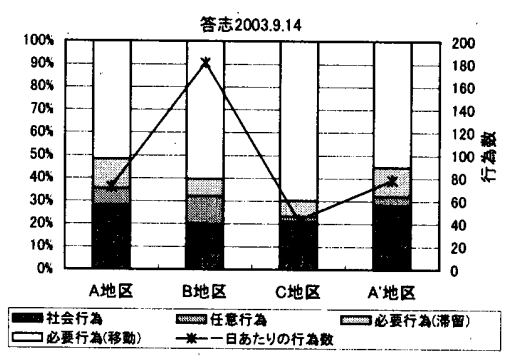

Fig.10-1 行為観察結果 (答志)

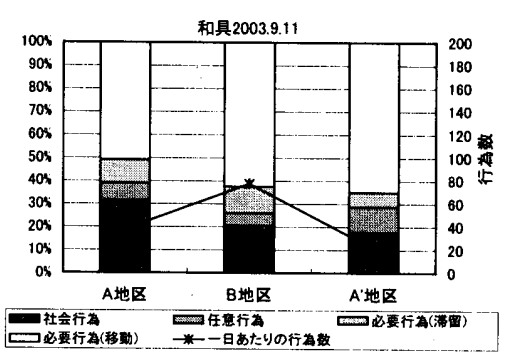

Fig.10-2 行為観察結果 (和具)

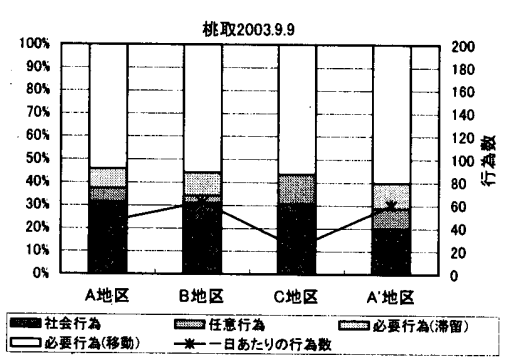

Fig.10-3 行為観察結果 (桃取)

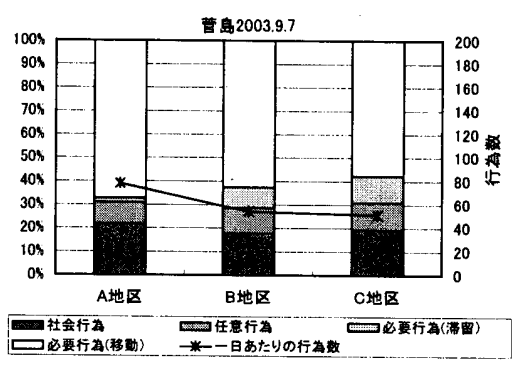

Fig.10-4 行為観察結果（菅島）

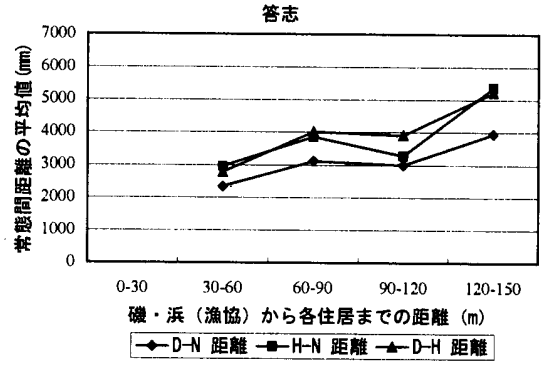

Fig.13-1 磯・浜（漁協）から各住居までの 距離と常態間距離の関係（答志）

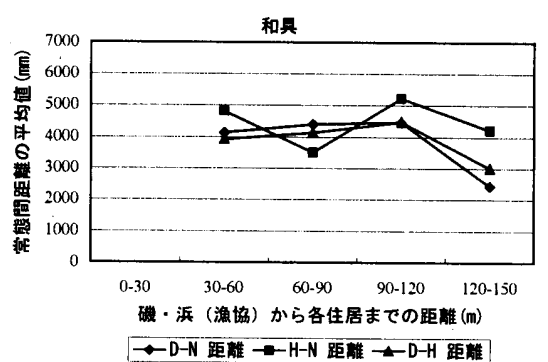

Fig.13-2 磯・浜（漁協）から各住居までの 距離と常態間距離の関係（和具）

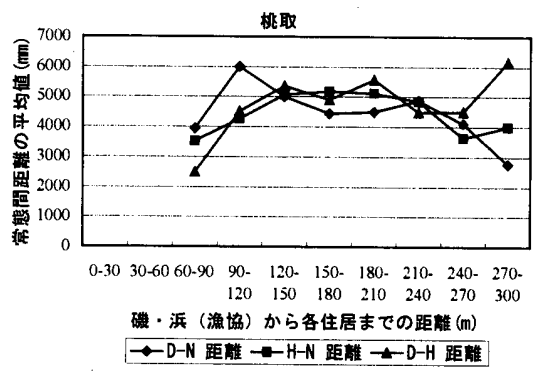

Fig.13-3 磯・浜（漁協）から各住居までの 距離と常態間距離の関係（桃取）

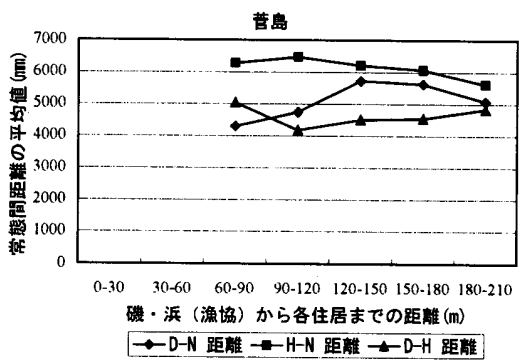

Fig.13-4 磯・浜（漁協）から各住居までの 距離と常態間距離の関係（菅島） 
同様に西側・北側を 2 つ磯・浜に挟まれるため、 $(0-210 \mathrm{~m})$ 地点で は西側の磯・浜、(210-300m)地点では北側の磯・浜によるものと考 えられる。菅島では磯・浜 (漁協) から $90 \mathrm{~m}$ 地点付近が常態間距離 の変曲点である（Fig.13-4）。磯・浜（漁協）から $90 \mathrm{~m}$ 以内の地区 では D-N 距離（世帯主と近所）は D-H 距離（家族同士）よりも短 く、近所との結びつきが強い。90m 以上離れて奥側（山・崖等の傾 斜地側）になるにつれて、D-H 距離（家族同士）は D-N 距離（世帯 主と近所）よりも短くなり、世帯の独立性が高まっている。以上、

「距離感覚」は屋外空間での行為数・行為内容と磯・浜（漁協）か ら各住居までの距離や集落空間の構成と密接に関係している。磯・ 浜（漁協）近傍の住居ほど、個人とその家族・近所との物理的空間 距離・心理的距離は短い。離島漁業集落では、集落空間の構成だけ でなく「距離感覚」も自己相似的構造をしているといえよう(Fig.14)。

\section{7.総括}

I : 常態位置の型は、答志・和具では A type、桃取では A・B type、 菅島では B type を基本型とし、各住居の敷地形状や周辺環境の条件 に合わせてその他の型へと派生する。

II：常態位置の差異は、住居が位置する周辺環境条件・営む漁業形 態・集落行事 (慣習) や漁場管理の方法・集落の形成プロセスとの 関連が考えられる。特に答志島・菅島での「D」・「H」は、漁業生 産の占める割合が高い集落ほど、屋外空間に近接する傾向がある。 III : 答志島・菅島の 4 集落の事例では、常態間距離の平均值は漁業 生産の占める割合が高い集落ほど家族同士よりも近所との方が短く、 その割合が低い集落ほど家族同士の方が近所よりも短くなっている。 IV : 答志では D-N 距離・H-N 距離が社会距離・遠方相 $(2.1-3.6 \mathrm{~m})$ が最も多いのに対して、他の 3 集落では D-N 距離・H-N 距離・D-H 距離ともに公衆距離・近接相 (3.6-7.5m) が最も多い。

$\mathrm{V}$ : 常態位置の主な型である A・B type では、常態位置同士を仕切 る空間装置が「引き違い建具」であることを基本型とする。D-N 距 離・D-H 距離が短くなるにつれて可動式装置が存在するのに対し、 H-N 距離では固定式装置が存在する傾向がある。

VI : 各集落ともに、磯・浜に近いほど屋外空間では数多くの行為が 発生し、特に社会行為が最も多い。それに関連して、「D」「H」は 磯・浜（漁協）に近い住居ほど屋外空間に近接する（常態間距離は 磯・浜 (漁協) 近傍に位置する住居ほど短く、磯・浜（漁協）から 各住居までの距離が離れるほど長い)。

離島漁業集落では磯・浜を中心に融通性を備えた高密集住空間が 形成されている。生産・生活が一体的に輻輳することで相互扶助・ 協働が成立し、地縁的地域共同体を形成している。住居単位では、 各住居にある外流しにより、「内と外」の生活が連続的になり、近 所との常態間距離が短くなる。また、両者を仕切る空間装置は可動 式が多く、交流を容易に誘発・制御できる。集住単位では、屋外空

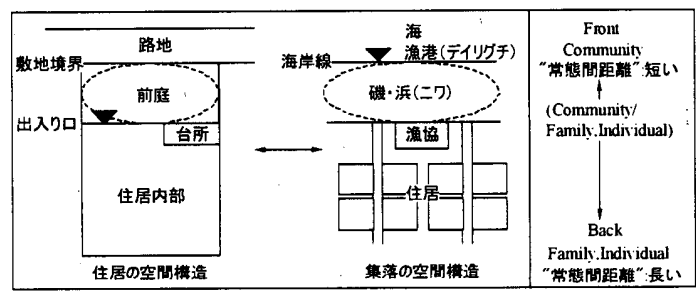

Fig.14 離島漁業集落における自己相似的構造
間に井戸・洗い場等の漁業生産に関する作業空間や協働の場が数多 く存在し、個々の生活者と近所とを結び付ける役割を果たしている。 環境単位では、各住居の建築面積が非常に狭小であるために庭を持 たないことが多く、磯・浜を生産・生活・交流の中心として有効に 活用している。磯・浜は単に波・風等の天候状態を日々確認するだ けでなく、夕涼みや散歩・近所との立ち話等の交流を行ううウとし て機能することで、「距離感覚」は磯・浜に近いほど短く、集落空 間全体に輻輳している。漁業集落での「高密集住」は以上のような 各システムを潜在的に序列化・体系化させることで成立していると いえよう。今後、漁業集落で生産・生活空間の環境整備等を行う場 合は、住居の「内と外」の連続性や日常生活での領域性を積極的に 継承することで、集落環境を更新しつつも個と集団の結びつきを維 持していくことができると考えられる。課題として生活者の属性 (年 齢・居住年数等) と「距離感覚」の関係、常態間距離を経路距離と して計測した場合の「距離感覚」について探求したいと考えている。

\section{謝辞}

大貫雅也 ・尾川陽一・村上直人君、答志島 - 菅島の皆様に御協力 を頂き、匿名查読者に大変貴重な御指摘を賜りました。文科省・日 本大学上り平成 $13 \sim 15$ 年度私立大学等経常費補助金特別補助・大学 院重点特別経費・研究科分・学生分の助成を受けた事を感謝します。

補注

1)「常態」の語義は「いつもの状態・普通の状態」である（岩波書店広辞 苑第五版の pp.1321 参照) 。

2）「常居」の語義は「家人の平常の居室・襃居」であり、「襃扂」とは「普 段居るところ」である(岩波書店広辞苑第五版の pp. $1300 、 p p .811$ 参照)。

3) 常態位置は、個人が任意に選ぶ特定の場であるため、常態位置の型は必 ずしも間取りの構成と一致するとは限らない。

4) 文献 12 のp.173 参照。

文献

1）宗正敏、宮崎隆昌：沿岸漁村地域に於ける集落の構成と特性（志摩・熊 野灘沿岸地域の整備計画に関する調查・研究その1), 日本建築学会論文 報告集, 第 270 号.pp.117-125,1978.8

2）宗正敏、宮崎隆昌：沿岸漁村地域に於ける複合集落の類型的性格につい て(志摩・熊野灘沿岸地域の整備計画に関する調査研究・その 2), 日本 建築学会論文報告集,第 271 号,pp.95-103,1978.9

3）大内厷友、宮崎隆昌、宗正敏：漁協を中心にとらえた漁港と集落の圈域 の構成に関する実証的研究-沿岸漁村地域における圈域の構成その $1-$, 日 本建築学会計画系論文報告集,第 369 号,pp.72-81,1986.11

4）大内宏友、宮崎隆昌、宗正敏 : 漁協を中心にとらえた圈城の特性とその 変容に関する実証的研究-沿岸漁村地域における圈域の構成その 2-, 日本 建筑学会計画采論文報告集,第 382 号,pp.77-86,1987.12

5）山本健司、宮崎隆昌：離島集落の各住居における収納と住居間距離の関 係について-高密集住空間の各住居同士の「間合い」-,日本建築学会技術 報告集,第 18 号,pp.257-262,2003.12

6) 地井昭夫: 漁業集落の研究とその方法についての考察（漁村計画の方法 に関する基礎的研究・その 1), 日本建築学会論文報告集,第 237 号,pp.135-145,1975.11

7）地井昭夫：漁業集落の構造度・構造型と構造頑型（漁村計画の方法に関 する基䃈的研究 - その 2)，日本建築学会論文報告集，第 238 号,pp. $79-90,1975.12$

8）小泉正太郎、三国政勝：漁業地区における住居及び近隣の空間形成に関 する研究-その 1 千葉県勝山漁業集落の調査を通して-,日本建築学会論 文報告集,第312 号,pp.123-132,1982 2

9)仙田満、金城むつみ、尾関昭之介：建築の個体距離に関する研究-住宅 のデザインコードと外部空間計画, 日本建築学会計画系論文報告集,第 423 号.pp.41-48,1991.5

10）仙田満、矢田努、尾関昭之介：住み手の意識からみた建築の個体距嵦建築の個体距離に関する研究 (その2), 日本建築学会計画系論文報告集, 第 435 号.pp.33-40,1992.5

11）古賀紀江、高橋鹰志：一人暮らしの高齢者の常座をめぐる考察-高齢者 の住居における居場所に関する研究その1,日本建築学会計画系論文集, 第 494 号,pp.97-104,1997.4

12）エドワード・ホール：かくれた次元,日高敏隆・佐藤信行訳,みすず書 房, 1970

13）金栄㚞、高橋鷹志：密集住宅地の「住戸群」における路地と隙間の役割 に関する研究,日本建築学会計画系論文集,第 469 号,pp.87-96,1995.3

(2004年 1 月 9 日原稿受理， 2004 年 6 月 3 日採用決定 $)$ 